\title{
認知症者の家族介護者のストレス (1)
}

\author{
介護時間の長さと起床時コルチゾール反応との関連性

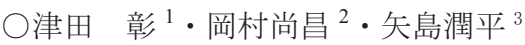 \\ ( 1 久留米大学文学部心理学科. 2 同大学医学部高次脳疾患研究所 $\cdot 3$ 別府大学文学部人間関係学科) \\ キーワード：認知症者の家族介護者、介護時間、起床時コルチゾール反応（CAR）
}

\section{Caregiving stress in Dementia Family Care Givers (1)}

\author{
Relation of caregiving hours per day with cortisol awaking response \\ Akira TSUDA $^{1}$, Hisayoshi OKAMURA ${ }^{2}$ and Jumpei YAJIMA ${ }^{3}$ \\ ( ${ }^{1}$ Department of Psychology, Kurume University, ${ }^{2}$ Cognitive and Molecular Research Institute of Brain Diseases, Kurume University, \\ ${ }^{3}$ Department of Human Studies, Beppu University)
}

Key words: Dementia family caregivers, Length of Caregiving hours, Cortisol awaking response (CAR)

\section{目 的}

認知症者を在宅で介護する家族では、深刻な身体的、精神 的問題を抱えることが明らかにされ、その背景要因について も解明が進んできている（Gallagher-Thompson et al., 2008）。 しかしながら、在宅認知症者を介護する家族の介護ストレス がどのような心理社会的要因を媒介として、またどのような 生物学的基礎過程を経て生じ、どのような健康-病気の結果に 至るのかについての詳細な理解は十分に進んでいるとは言え ない。

近年、過重労働などによってストレス反応が慢性化した結 果として、視床下部-脳下垂体-副腎皮質系に機能異常が生じ、 これらの変調が起床時から起床 30 分後に特徵的に見られる コルチゾール分泌の上昇(これを、起床時コルチゾール反応、 CAR と称寸る）が起こらなくなることが報告されている。も し、在宅で認知症者を介護する家族の介護負担が慢性化した 状態に陥っているとするならば、休息状態から活動状態に切 り替わる起床時に本来発現すべき CAR が起こらないかもし れない。このような現象は、アロスタッティク負荷と呼ばれ、 健康-病気の結果を媒介する主要な生物学的要因として注目 されている。

そこで、本研究では、介護ストレスの客観的指標としての CARに注目して、介護ストレスの生物学的基礎過程とその関 連要因を包括的に検討した。唾液中 CAR が、研究 1 では、1 日当たりの介護時間の長さによって、第 2 研究では、介護者 の主観的健康感によって、第 3 研究では、介護者の人種によ ってどのように異なるのか調べた一連の結果を、3 つの演題 で連続報告する。

\section{方 法}

被験者：参加の同意の得られた米国サンフランシスコ周辺 在住の認知症患者を持つ白人系ならびにヒスパニック・ラテ ン系米国人の家族介護者 156 名（年齢 $57.8 \pm 1.4 ）$ を対象に

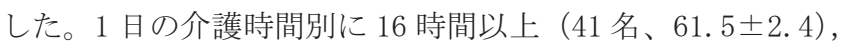
5-15 時間（75 名、57.0 1 1.5）及び 4 時閒以下（40 名、 54.6 土2.0）の 3 群に設定し比較した。対象者の属性や募集などの 詳細は、Gallagher-Thompson et al. (2008) を参照。

手続き：唾液採取は、起床時、起床後 30 分、17 時及び 21 時の 4 回行った。質問紙に関しては、被験者をスタッフが訪 問して記入を求めた。

質問紙：主観的ストレス反応の評価は、SF-36（全体的健康 感、身体機能、日常役割機能、身体の痛夕、社会生活機能、 活力及び心の健康などの下位尺度を含む)、Center for Epidemiological Studies Depression Scale (CES-D)、Zarit 介護負担感尺度、Perceived Stress Scale（PSS）によって評
価した。

コルチゾールの測定：唾液を試料にして、測定用 Kit（DRG 社）を用いて測定した。

\section{結果と考察}

起床時のコルチゾール分泌量は 3 群間にまったく違いがな かったが、起床 30 分後のコルチゾール分泌の有意な上昇 (i.e., CAR） は、1 日当たりの介護時間の長さが 4 時間以下 の介護者でのみ認められた。これに対して、介護時間が 5-15 時間と 16 時間以上に及ぶ介護者では、CARがまったく起こら ず、 4 時間以下の介護者と比較して、起床後 30 分のコルチゾ 一ルは有意に低かった。17 時、21 時のコルチゾール分泌量は、 3 群いずれも低く、朝から夕方にかけて著明に減少する日内 リズムを等しく示した。これらの知見は、介護時間が長い介 護者の HPA 系に変調が生じていること、それは慢性的な介護 ストレスによるアロスタッティク負荷を反映しているように 思われる。

コルチゾール反応と同様に、介護時間が 16 時閒を超える介 護者では、4 時間以下の介護者と比較して、SF-36 の下位尺度 の身体機能と日常役割機能が有意ないし有意傾向をもって低 下した。これらの知見は、1 日の介護時間長時間に及ぶと、 身体的愁訴が高くなるとともに、日常生活活動に支障をきた すことを明らかにしており、自覚的にも、他覚的にも疲弊し ている状態を伺わせている。

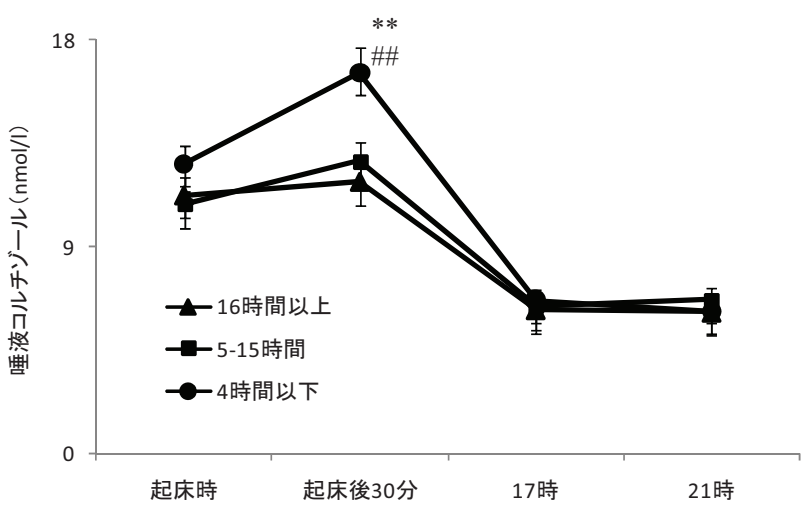

図 1 介護時間の関数としての唾液コルチゾール反応の変化 $* * \mathrm{p}<0.01$ (vs. 起床時)、 \#\#p<0.01（vs.16 時間以上）

脚注 : 本研究は、D. Gallagher-Thompson 教授（Stanford 大学） と L.W. Thompson 教授（Pacific 心理職専門大学院）との共 同で行われたもので、演者らは唾液コルチゾールの測定を 分担した。 